\title{
Four-Corner Fusion with Locking Dorsal Circular Plate versus Headless Compression Screws: A Clinico-Radiological Comparative Study
}

\section{Artrodesis de cuatro esquinas con placa circular dorsal bloqueada versus tornillos canulados de compresión sin cabeza: estudio clínico-radiológico comparativo}

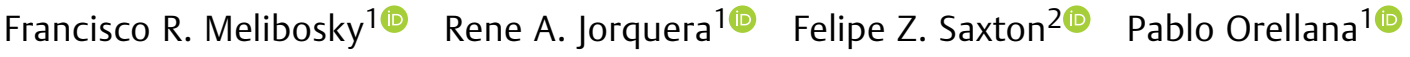 \\ Diego Junqueras ${ }^{2,3(1)}$ Camila Azócar ${ }^{10}$

\begin{abstract}
Address for correspondence Francisco Melibosky, MD, Facultad de Medicina de la Universidad de Valparaíso, Avenida Santa María 1.810, Providencia, Santiago, 1111, Chile
\end{abstract} \\ (e-mail: francisco.melibosky@gmail.com).
}

\footnotetext{
${ }^{1}$ Hand Surgery and Microsurgery Unit, Department of Traumatology and Orthopedics, Clínica Indisa - Facultad de Medicina de la Universidad de Valparaíso, Santiago, Chile

2 Hand Surgery and Microsurgery Unit, Department of Traumatology and Orthopedics, Facultad de Medicina Clínica Alemana de Santiago - Universidad del Desarrollo, Santiago, Chile

${ }^{3}$ Hand Surgery Unit, Department of Traumatology and Orthopedics, Hospital de la Florida, Santiago, Chile
}

Rev Iberam Cir Mano 2021;49(2):e105-e114.

\author{
Abstract \\ Keywords \\ - SNAC \\ - SLAC \\ - partial carpal \\ arthrodesis \\ - four-corner fusion \\ - dorsal locking plate \\ - cannulated \\ compression screws
}

Introduction Four-corner fusion is a technique for the treatment of carpal advanced collapse. It consists of scaphoid excision and arthrodesis of the lunate, triquetrum, hamate, and capitate bones. This can be accomplished with different kinds of osteosynthesis. In the first reports of the use of a circular plate, poor outcomes are described, with high rates of non-union, which decreased in later studies, which highlight certain aspects of the surgical technique.

Objective To report our experience with four-corner fusion with the use of a dorsal locking plate (Xpode, Trimed Inc., Santa Clarita, CA, US), and compare it with another traditional fixation method (3.0-mm headless compression screws [HCSs], Synthes, Slothurn, Switzerland), with an emphasis on union, an assessment of the fincitonal outcomes, and the presence of complications.

Material and Methods A comparative study of two prospective series of patients operated on through two fixation techniques for four-corner fusion using autologous bone graft from the iliac crest.

The first group of patients, evaluated between 2010 and 2012, underwent osteosynthesis with 2 HCSs, with a minimum follow up of 18 months. The second group, received

October 5, 2020

accepted

June 9,2021
DOI https://doi.org/

$10.1055 / \mathrm{s}-0041-1739239$. ISSN 1698-8396.

\footnotetext{
(c) 2021. SECMA Foundation. All rights reserved.

This is an open access article published by Thieme under the terms of the Creative Commons Attribution-NonDerivative-NonCommercial-License, permitting copying and reproduction so long as the original work is given appropriate credit. Contents may not be used for commercial purposes, or adapted, remixed, transformed or built upon. (https://creativecommons.org/ licenses/by-nc-nd/4.0/)

Thieme Revinter Publicações Ltda., Rua do Matoso 170, Rio de Janeiro, RJ, CEP 20270-135, Brazil
} 
evaluated between 2011 and 2014, underwent osteosynthesis with a dorsal locking plate, with a minimium foloow up of 12 months. The patients were operated on by four different surgeons in four centers.

The patients were evaluated with radiographs to establish the presence of union and the time it took to occur. In case of doubt, union was confirmed through a computed tomography (CT) scan at 8 weeks postoperatrively. We also assessed the range of motion, the presence of complications, and function through the Disabilities of the Arm, Shoulder and Hand (DASH) questionnaire and a grip strength score.

Results We achieved a union rate of $100 \%$ in both groups at similar times. In the dorsal locking plate group, we obtained better full range of motion, particularly in wrist extension, which was statistically significant $(p=0.0016)$, as well as lower DASH scores, which was also statistically significant $(p=0.0066)$. Complications were only present in two patients in the HCS group.

Conclusion Both techniques are valid and reproducible for the treatment of wrists with scapholunate advanced collapse (SNAC) and scaphoid non-union advanced collapse (SLAC). Based on the outcomes, with the Xpode plate, the patients presented better ranges of motion and DASH scores; therefore it may be an excellent fixation option in the open four-corner fusion surgical technique. The entry point and configuration of the HCS are fundamental variables to analyze.

The union rate of $100 \%$ obtained in the present study contrasts with the high rates of non-union reported in the literature published in the early 2000 s.

\section{Resumen}

Introducción La artrodesis de cuatro esquinas es una técnica para el tratamiento de colapsos avanzados del carpo. Consiste en realizar una escafoidectomía asociada a artrodesis de los huesos semilunar, piramidal, ganchoso y grande. La cirugía se puede realizar con distintos tipos de osteosíntesis. En los primeros reportes de uso de las placas circulares dorsales, se describen malos resultados, con altas tasas de no unión, las cuales disminuyeron en los estudios posteriores, en los cuales se pone especial hincapié en puntos de la técnica quirúrgica.

Objetivo Reportar nuestra experiencia en la artrodesis de cuatro esquinas con el uso de una placa dorsal bloqueada (Xpode, Trimed Inc., Santa Clarita, CA, EEUU), y compararla con otro método de fijación tradicional (tornillos canulados de compresión sin cabeza de $3.0 \mathrm{~mm}$, Synthes, Solothurn, Suiza), con énfasis en la consolidación, evaluación de resultados funcionales, y presencia complicaciones.

Material y Métodos Estudio comparativo de dos series de pacientes operados con dos técnicas distintas de osteosíntesis para una artrodesis de cuatro esquinas utilizando injerto autólogo de cresta iliaca.

En un primer grupo, evaluado entre el 2010 y el 2012, se usó osteosíntesis con 2 tornillos canulados de compresión sin cabeza, con un seguimiento mínimo de 18 meses, y en otro grupo, evaluado entre el 2011 y el 2014, se usó osteosíntesis con placa bloqueada dorsal, con un seguimiento mínimo de 12 meses. Estos fueron operados en cuatro centros por cuatro cirujanos distintos.

Se les evaluó con radiografías, para determinar la presencia de consolidación y el tiempo de la misma. En caso de duda, se certificó la consolidación con tomografía axial computarizada (TAC), a las ocho semanas postquirúrgicas. También se evaluaron los rangos de movimiento, la presencia de complicaciones, y la función con escalas las escalas de discapacidades del brazo, hombro y mano (Disabilities of the Arm, Shoulder and Hand, DASH, en inglés), y de fuerza de puño. 


\section{Palabras clave \\ - SNAC \\ - SLAC \\ - artrodesis parcial del carpo \\ - artrodesis de cuatro esquinas \\ - placa bloqueada dorsal \\ - tornillos canulados de compresión}

Resultados Logramos tasas de consolidación del 100\% en ambos grupos, con tiempos similares. Destaca en el grupo de placas el mejor rango de movimiento total y en especial de la extensión, con una diferencia estadísticamente significativa $(p=0,0016)$, al igual que la obtención de puntajes de DASH más bajos, con una diferencia estadísticamente significativa $(p=0,0066)$. Sólo en el grupo de tornillos hubo dos casos de complicación de la osteosíntesis.

Conclusión Ambas técnicas son válidas y reproducibles para el tratamiento de las muñecas con colapso avanzado del carpo secundario a una lesión escafolunar (scapholunate advanced collapse, SLAC, en inglés) y colapso avanzado del carpo secundario a una no unión del escafoides (scaphoid non-union advanced collapse, SNAC, en inglés). Con base en los resultados, consideramos que, con la placa Xpode, los pacientes presentan mejores rangos de movimiento y puntajes en el DASH, por lo que puede ser una excelente alternativa para la artrodesis de cuatro esquinas con técnica abierta. La configuración y el sitio de entrada en el caso de usar tornillos son temas fundamentales a analizar.

La tasa de consolidación del $100 \%$ obtenida en este estudio contrasta con las altas tasas de no unión de las placas dorsales circulares reportadas en la bibliografía en los años 2000 .

\section{Introduction}

Degenerative wrist osteoarthritis can be a severely impairing condition due to range of motion (ROM) restriction and pain during daily living activities. As a cause of functional disability, it is estimated to affect more than $10 \%$ of the United States population. $^{1}$

In the past, the standard treatment for these degenerative disorders used to be total joint arthrodesis. ${ }^{2}$ Although it provides predictable pain relief, the concomitant complete loss of movement is a costly trade-off for patients. ${ }^{3}$

Congenital carpal fusions or coalitions reported as radiographic findings in otherwise normal subjects, ${ }^{4-6}$ presenting with no pain or disability, suggested that intercarpal arthrodesis could acceptably restore function in an injured wrist and eliminate the need for total wrist arthrodesis. ${ }^{7,8}$

The first partial carpal arthrodesis was described in the international literature by Thornton in $1924 .^{9}$ Next, Sutro (1946) and Helfet (1952) published outcomes from a scaphocapitate arthrodesis. $^{10,11}$ In the 1960 s, Graner et al. ${ }^{12}$ described an intercarpal arthrodesis with lunate or proximal scaphoid fragment resection, while Peterson and Lipscomb, ${ }^{7}$ at the Mayo Clinic, reported success in the treatment of degenerative osteoarthritis secondary to scaphoid nonunion, posttraumatic scaphoid subluxations, and Kienböck disease. Then, in 1980, Watson ${ }^{13,14}$ popularized the "triscaphoid arthrodesis', that is, scaphoid-trapezium-trapezoid arthrodesis.

"Four-corner fusion" was first described in 1984 by Watson and Ballet ${ }^{15}$ to treat advanced carpal collapses secondary to a scapholunate lesion (scapholunate advanced collapse, SLAC). As such, it is part of our arsenal for wrist salvage treatment, consisting of a scaphoidectomy with arthrodesis of the capitate, lunate, triquetrum, and hamate bones along with midcarpal joint fusion. ${ }^{11,16,17}$ This technique spares the radiolunate joint movement, resulting in an osteoarthritisfree wrist.

The most common indications for this technique are SLAC, the main degenerative pattern, ${ }^{2}$ and scaphoid nonunion advanced collapse (SNAC). The SLAC and SNAC degenerative patterns occur in three stages, and stages II and III are indications for four-corner fusion. ${ }^{18-22}$ In the first stage, degenerative changes are observed at the radial styloid and the distal scaphoid pole both in scaphoid non-union and scapholunate dissociation. In the second stage of SLAC, the degenerative changes progress from the distal radius to the proximal scaphoid pole; in SNAC, however, this space is spared, and the involvement progresses towards the scaphocapitate joint. The third stage of both SLAC and SNAC is characterized by capitolunate joint involvement while the radiolunate joint is spared. ${ }^{15,22-27}$ Preservation of the radiolunate joint is the basis to indicate this surgical technique; however, advanced degenerative changes at this joint are a definitive contraindication for this procedure, along with ulnar translation. ${ }^{11,16,23}$ Some surgeons prefer a proximal carpectomy in the absence of capitolunate degeneration as an alternative to four-corner fusion. ${ }^{18,21,28-30}$

Another group of patients who may benefit from fourcorner fusion consists of subjects with midcarpal instability, ${ }^{17,31}$ scaphoid chondrocalcinosis advanced collapse (SCAC) or other arthritides of rheumatological origin, ${ }^{32,33}$ chronic perilunate instabilities, ${ }^{34}$ and dynamic chronic or non-dissociative carpal instabilities in which reconstructive treatments have failed. ${ }^{35,36}$

The surgical technique has undergone very few modifications since its first description, and the debate focuses on fixation or osteosynthesis methods. Initially, fixation was performed with multiple Kirschner wires; ${ }^{37}$ next, staples $^{21,38}$ or compression screws in different positions were 
used, ${ }^{11,39}$ followed by dorsal circular carpal plates, ${ }^{11}$ which more recently have been innovated with lock designs.

At first, the dorsal circular plate had poor outcomes, with high non-union rates (48-63\%); ${ }^{40,41}$ however, authors such as Bedford and Yang $^{42}$ and Merrel et al. ${ }^{43}$ described union rates of $100 \%$, placing special emphasis on aspects of the surgical technique. ${ }^{44}$

The present study aims to report our experience with four-corner fusion using a radiolucent locking dorsal circular plate (Xpode ${ }^{\circledR}$, Trimed Inc., Santa Clarita, CA, US), and to compare it with another fixation method (3.0-mm cannulated headless compression screws [HCSs], Synthes, Solothurn, Switzerland) regarding consolidation, functional outcomes, and complication rates. We believe that this technique presents higher rates of union, consistent with traditional osteosynthesis methods.

\section{Material and Methods}

The present is a comparative study of two series of patients, totaling 17 subjects, submitted to two different osteosynthesis techniques to perform four-corner fusion.

The patients were divided into two groups according to the surgical technique. The first group underwent fourcorner fusion with two cannulated HCSs, according to the Richards et al. ${ }^{16}$ technique. The second group was submitted to an osteosynthesis technique with the Xpode plate, according to the technique described by Shin ${ }^{11}$ and by Rhee et al. ${ }^{45}$

Both groups were operated on by four orthopedic surgeons in four different medical centers: Hospital de la Fuerza Aérea de Chile, Clínica Indisa, Clínica Alemana de Santiago, and Hospital de la Dirección de Previsión de Carabineros de Chile (DIPRECA). All subjects were radiographically evaluated to determine the presence of consolidation and the time until its completion. In case of doubt, union was assessed with a computed tomography (CT) scan eight weeks after surgery (-Figure 1).

The variables for functional analysis of both groups included postoperative ROMs, complications, the need for new surgeries, grip strength determination, and the score on the Disabilities of the Arm, Shoulder, and Hand questionnaire.

Data collection and tabulation were performed using the Microsoft Office Excel (Microsoft Corp., Redmond, WA, US) software. The statistical analysis was performed on the Stata (Statacorp, LLC, College Station, TX, US) software, version 12.0. The continuous variables were analyzed with the Student $t$-test and the Wilcoxon-Mann-Whitney test according to the normal distribution, whereas the categorical variables were analyzed with the Chi-squared test. Statistical significance was set at $p<0.05$.

\section{Protocol Descriptions}

As aforementioned, four-corner fusion underwent few modifications since its original description. It is critical to remember the key points in any partial carpal arthrodesis: 1) achieve adequate carpal reduction and alignment; 2) achieve adequate denudation of the articular surfaces; 3 ) add and supplement with a bone graft; and 4) provide adequate arthrodesis stabilization using some osteosynthesis material.

\section{Surgical Technique}

The procedure is performed under general plus brachial plexus anesthesia and arm ischemia, using the longitudinal dorsal wrist approach. Next, subcutaneous tissue dissection, sparing the sensitive dorsal branches of the radial and ulnar nerves, was performed, followed by a longitudinal incision of the extensor retinaculum between the third and fourth compartments and elevation of the Lister tubercle, releasing the tendon of the extensor pollicis longus muscle and separating it radially. The fourth compartment was opened, releasing the tendons of the extensor digitorum communis and separating them ulnarly. Then, a neurectomy of the posterior interosseous nerve was performed in the most proximal area, leaving the nerve stump as deep as possible, followed by a Berger et al. ${ }^{46}$ dorsal capsuloplasty. Scaphoidectomy, exposure of the carpal bones, and denudation of the articular surfaces to be instrumented (lunate-capitate, triquetrum-hamate, capitate-hamate, lunate-triquetrum)

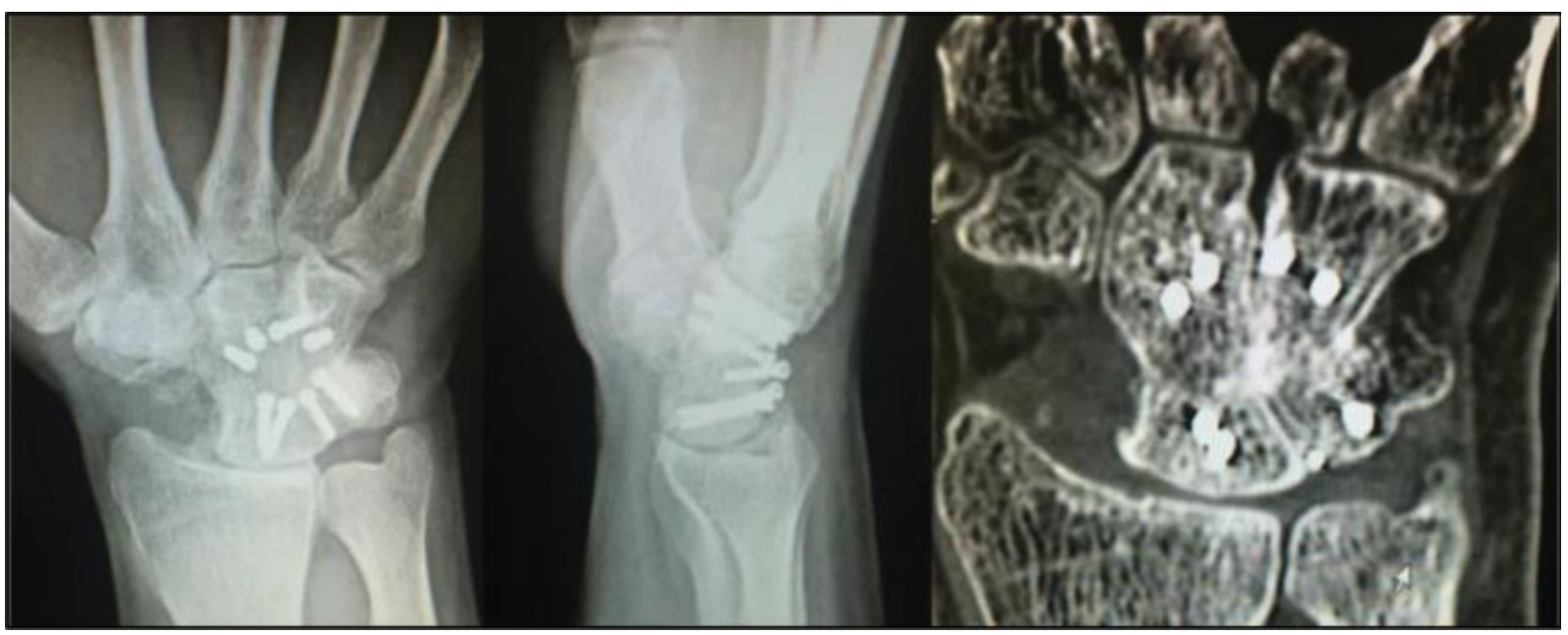

Fig. 1 Clinical case: postoperative radiograph and computed tomography scan to confirm satisfactory consolidation if required. 


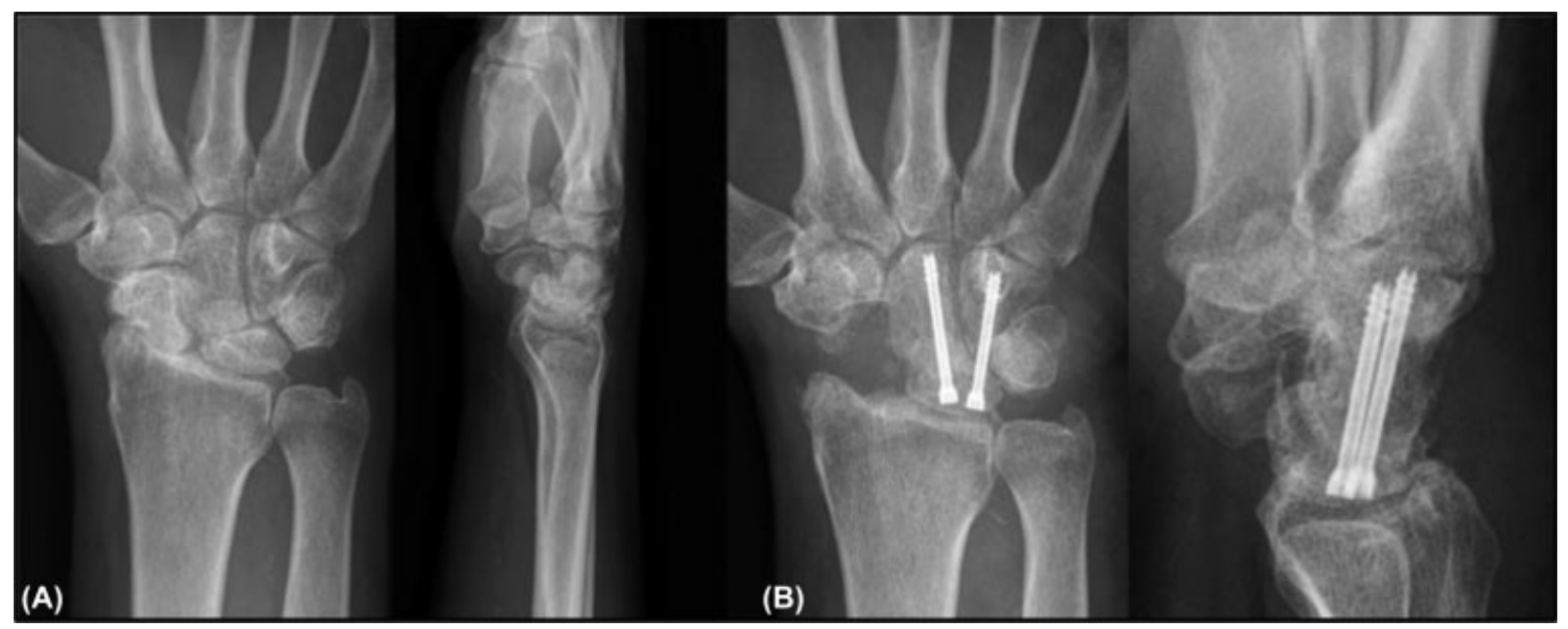

Fig. 2 (A) Preoperative and (B) postoperative radiographs of the surgical technique using cannulated headless compression screws (Richards et al. technique $\left.{ }^{16}\right)$.

were performed using gouges, spoons, and dental burs, followed by removal and cleaning of chondral debris. Up to this point, both techniques were similar, but from here on they differ according to the definitive stabilization with the selected osteosynthesis method.

${ }^{*}$ Group 1-Screws (Richards et al. ${ }^{16}$ ): correction of the carpal alignment with lunate reduction (for dorsal intercalated segment instability, DISI) and capitate migration; temporary stabilization with two Kirschner wires and the selected compression screws: one from the lunate to the capitate bones, and another from the lunate to the hamate bones. Two 3.0-mm HCSs were placed, from proximal to distal, with the lunate bone as an entry point. Finally, after the addition of an iliac crest bone graft, the capsulotomy was closed, followed by closure of the surgical wound in planes (-Figure 2).

${ }^{* *}$ Group 2 -Xpode plate (Shin ${ }^{11}$ and Rhee et al. ${ }^{45}$ ): correction of the carpal alignment with lunate reduction (for DISI) and temporary stabilization with two Kirschner wires: one from the radius to the lunate bones and another from the capitate to the triquetrum bones. After providing abundant iliac crest bone graft, the site for the placement of the Xpode plate was drilled, and the plate was definitively stabilized with two locking screws per corner ( - Figure 3 ), with care to achieve adequate radiocarpal mobility and avoid dorsal impingement. Finally, the capsulotomy was closed, followed by closure of the surgical wound in planes.

Subjects from both groups used a wrist immobilizer two weeks after surgery, until suture removal. Next, immobilization was performed with a short arm cast for four to six weeks. Subsequently, a kinesic rehabilitation protocol was instituted for ROM recovery.

\section{Results}

In total, 17 subjects were included; 8 patients were operated on from 2010 to 2012 with osteosynthesis using 2 HCSs, and 9 patients were operated on between 2011 and 2014 with a radiolucent locking dorsal circular plate made of a synthetic polymer called polyether-ether-ketone (PEEK).

The mean age in the first group was 45 years (range: $32-$ 64 years). This group consisted of six men and two women;

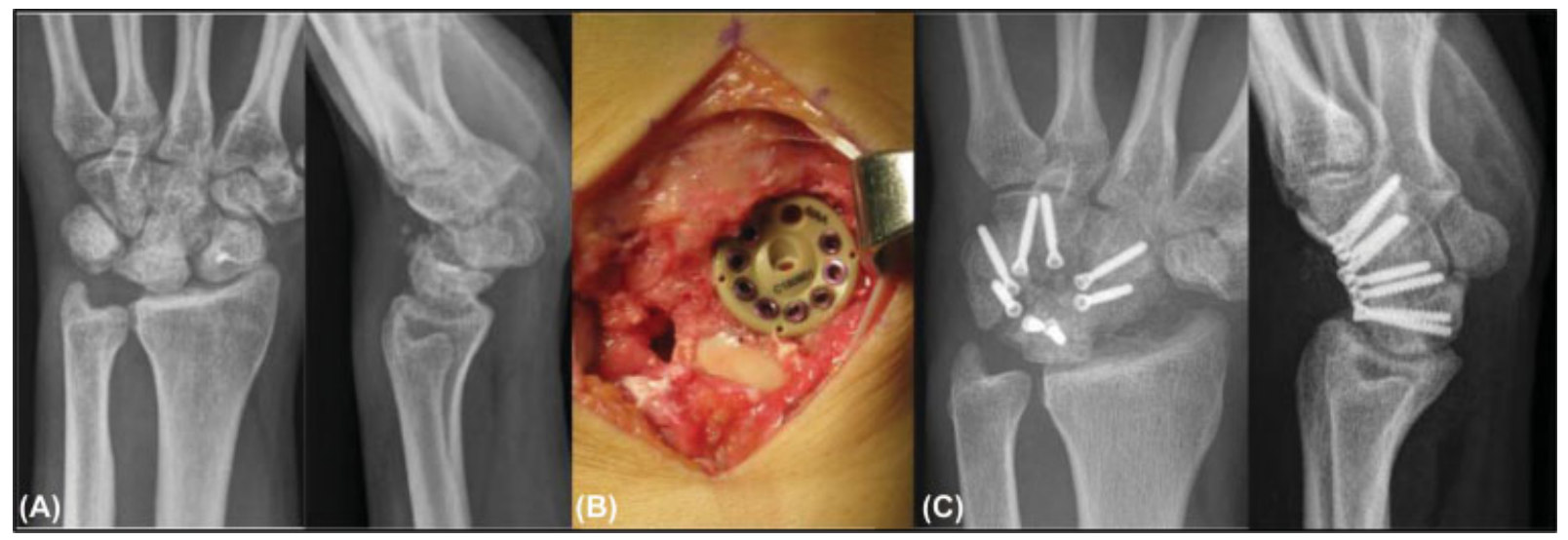

Fig. 3 (A) Preoperative radiograph, (B) intraoperative photograph: Xpode plate in situ with two screws per bone (corner) and autologous bone graft, and (C) postoperative radiograph of the surgical technique using a plate (Rhee et al. ${ }^{45}$ technique). 
Table 1 Comparison of outcomes in the plate and screw groups

\begin{tabular}{|l|l|l|l|}
\hline Outcome & $\begin{array}{l}\text { Plate } \\
(\text { Xpode) }\end{array}$ & Screws & $P$-value \\
\hline & $(\mathbf{N = 9 )}$ & $(\mathbf{N}=\mathbf{8})$ & $(\boldsymbol{p}<\mathbf{0 . 0 5})$ \\
\hline $\begin{array}{l}\text { Flexion-extension } \\
\text { range of motion }\left(^{\circ}\right)\end{array}$ & 78 & 67.8 & 0.131 \\
\hline Flexion $\left(^{\circ}\right)$ & 35.1 & 38.1 & 0.214 \\
\hline Extension $\left(^{\circ}\right)$ & 50.7 & 29.7 & $\mathbf{0 . 0 0 1}$ \\
\hline Radialization $\left(^{\circ}\right)$ & 13.1 & 15.6 & 0.478 \\
\hline Ulnarization $\left(^{\circ}\right)$ & 28.3 & 26.8 & 0.795 \\
\hline Strength $(\mathrm{kg})$ & 29.6 & 23.7 & 0.102 \\
\hline $\begin{array}{l}\text { DASH score } \\
\text { (points) }\end{array}$ & 5.3 & 15.2 & $\mathbf{0 . 0 0 6}$ \\
\hline Complications $(\%)$ & 0 & $\begin{array}{l}11.76 \\
(\text { osteolysis })\end{array}$ & 0.111 \\
\hline
\end{tabular}

Abbreviation: DASH, Disabilities of the Arm, Shoulder, and Hand questionnaire.

the dominant wrist was involved in five cases, and the nondominant wrist was affected in three cases. This group had three cases of SLAC and five of SNAC as etiological diagnoses. The average follow-up period was of 18 months.

In the second group, the mean age was 40 years (range: 18-62 years). This group consisted of eight men and one woman; the dominant wrist was involved in five cases and the non-dominant wrist was affected in three cases. This group had three cases of SLAC, three of SNAC, and three of instability and midcarpal osteoarthritis secondary to perilunate carpal lesions as etiological diagnoses. The average follow-up period was of 12 months.

Both groups were comparable, with no significant differences regarding age and gender. The ROMs, DASH scores, and grip strength were determined after six months of follow-up, as shown in -Table 1.

The mean flexion-extension ROM among the HCS group was of $68^{\circ}$, with an average flexion of $38.1^{\circ}$ (range: $20^{\circ}-45^{\circ}$ ) and an average extension of $29.7^{\circ}$ (range: $20^{\circ}-40^{\circ}$ ). In contrast, the mean flexion-extension ROM among the plate group was of $78^{\circ}$, with an average flexion of $27.2^{\circ}$ (range: $10^{\circ}-40^{\circ}$ ) and an average extension of $50.7^{\circ}$ (range: $30^{\circ}-75^{\circ}$ ). This difference in the extension range for both groups was statistically significant $(p=0.0016)$. There were no statistically significant differences regarding flexion, radialization, or ulnarization.

The mean DASH score was of 15.2 points in the HCS group, and of 5.3 points in the plate group, with a statistically significant difference $(p=0.0066)$. Grip strength showed no statistically significant differences between the groups.

The mean consolidation time was of 8.2 weeks in the HCS group, and of 8 weeks in the plate group, with no statistically significant difference $(p=0.408)$. Consolidation was achieved in $100 \%$ of the patients, with no cases of non-union
Table 2 Comparison of consolidation times

\begin{tabular}{|l|l|l|l|}
\hline Outcome & $\begin{array}{l}\text { Plate } \\
\text { (Xpode) }\end{array}$ & Screws & $P$-value \\
\hline & $(\mathbf{N = 9 )}$ & $(\mathbf{N = 8 )}$ & $(\boldsymbol{p}<\mathbf{0 . 0 5})$ \\
\hline Consolidation (weeks) & 8 & 8.25 & 0.408 \\
\hline Non-union (\%) & 0 & 0 & \\
\hline
\end{tabular}

in both series, which is consistent with the international literature (-Tables 2 and $\mathbf{3}$ ).

As for osteosynthesis complications, there were only two cases of osteolysis, which did not result in non-union, in the HCS group. In one case, a clinically-asymptomatic patient presented migration of one of the capitate-lunate screws on the control radiograph taken at sic months; since there was a risk of involvement of the radiocarpal articular surface, a new surgery was required for the removal of the osteosynthesis material nine months after the first procedure. The second patient presented persistent pain that did not subside with rehabilitation, so we decided to perform a total wrist arthrodesis, which is still pending.

\section{Discussion and Conclusion}

Four-corner fusion is a reliable and reproducible surgical procedure to treat stage-II and -III SLAC/SNAC wrists, preserving an adequate ROM. ${ }^{18,20,21,43,49}$

Throughout its history, several osteosynthesis methods have been used, since an optimal or perfect technique has clearly not been found. The traditional Kirschner wires described by Watson initially resulted in reports of low non-union rates (3-18\%) in the literature, ${ }^{16,23,28,49-51}$ but criticism of this technique can be made, because it is known that, biomechanically, Kirschner wires present deficiencies compared to more recent implants ${ }^{52}$ In addition, they are associated with considerable migration rates, tendon irritation, insertion-site infection, and patient discomfort. Staples also result in low non-union rates, and in complications such as dorsal impingement; ${ }^{50}$ their use was never considered in our institutions.

There were no cases of non-union using cannulated HCSs, since we achieved consolidation in $100 \%$ of the patients, which is in line with the reports in the literature. $16,39,40,50$ There were no cases of conversion to total wrist arthrodesis in any of our series, even though the conversion rate ranges from $2.4 \%$ to $29 \%{ }^{28,40,41,51,53-55}$ However, in the HCS group, there is a procedure pending for one patient, due to residual pain, osteolysis caused by the cannulated HCSs, and radiolunate joint wear (-Figure 4).

We must bear in mind that the rate of total wrist arthrodesis may be falsely low due to relatively short follow-up periods. Nevertheless, Bain and Watts ${ }^{50}$ and Watson and $\mathrm{Ryu}^{22}$ showed that mobility, pain scores, and the conversion rate to total arthrodesis were not different regarding patients with follow-ups consultations held 1 and 10 years after surgery. 
Table 3 Comparison of outcomes with other four-corner fusion series

\begin{tabular}{|c|c|c|c|c|c|c|}
\hline Series & Follow-up & Sample & Osteosynthesis & F-E ROM & DASH & Non-union \\
\hline & (years) & (n) & & $\left({ }^{\circ}\right)$ & (points) & (\%) \\
\hline Watson and Ballet ${ }^{15}$ (1984) & 3.6 & 252 & Kirschner wires & - & - & $3 \%$ \\
\hline Vance et al. ${ }^{40}(2005)$ & 4.9 & 31 & $\begin{array}{l}\text { Kirschner wires, staples, } \\
\text { and screws }\end{array}$ & 65 & 8 & $3 \%$ \\
\hline Vance et al. ${ }^{40}(2005)$ & 4.9 & 27 & Spider plate & 65 & 27 & $26 \%$ \\
\hline Richards et al. ${ }^{16}$ (2011) & 4 & 21 & Screws (HCSs) & $30-60$ & - & $5 \%$ \\
\hline Ozyurekoglu and Turker ${ }^{39}$ (2012) & 2.3 & 33 & Screws & 71 & 13 & $6 \%$ \\
\hline Merrell et al. ${ }^{43}(2008)$ & 3.8 & 28 & Spider plate & 61 & - & $0 \%$ \\
\hline Kendall et al. ${ }^{41}$ (2005) & 1.6 & 18 & Spider plate & 50 & - & $62.50 \%$ \\
\hline Rhee et al. ${ }^{45}$ (2013) & 1.33 & 23 & Xpode & - & - & $4 \%$ \\
\hline Luegmair and Houvet $^{62}$ (2012) & 5.25 & 24 & Xpode & 64 & 19.1 & $8 \%$ \\
\hline Tchurukdichian $^{47}$ (2006) & 1.4 & 24 & Xpode & 61 & - & $8 \%$ \\
\hline $\operatorname{Roux}^{48}(2006)$ & 0.75 & 11 & Xpode & 63 & - & $9 \%$ \\
\hline Present study & 2.5 & 9 & Xpode & 78 & 5.3 & $0 \%$ \\
\hline Present study & 3 & 8 & Screws & 67.8 & 15.2 & $0 \%$ \\
\hline
\end{tabular}

Abbreviations: DASH, Disabilities of the Arm, Shoulder, and Hand questionnaire; F-E ROM, flexion-extension range of motion; HCSs, headless compression screws.

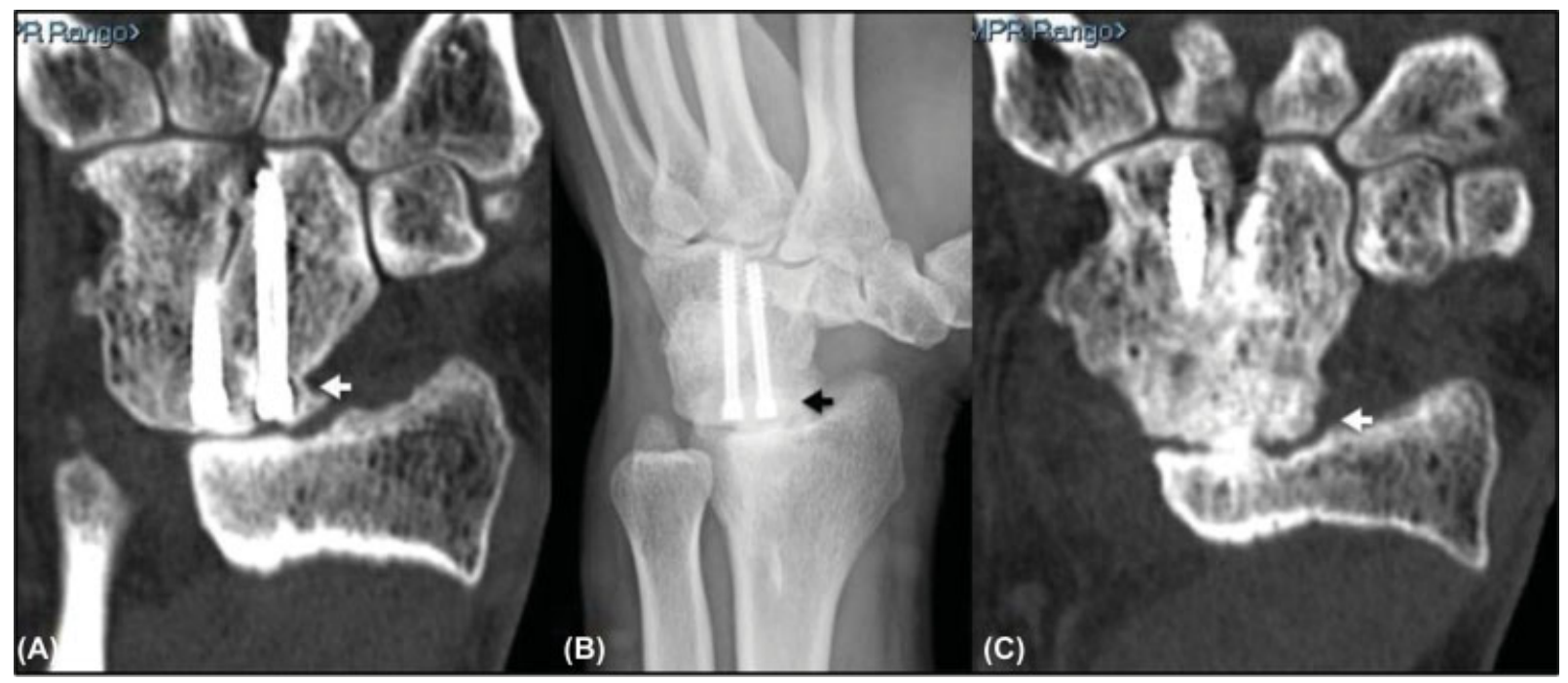

Fig. 4 Clinical case: $(A, B)$ ccrew osteolysis in postoperative radiograph and computed tomography scan; (C) progression of the degenerative process and osteoarthritis.

We performed the surgical technique described by the first authors to use screws in four-corner fusion, Richards et al.: ${ }^{16}$ fixation with two proximal-to-distal screws entering the radiolunate joint. Despite the good outcomes, perforation of the lunate articular cartilage causes defects on the articular surface, including iatrogenic lesions, resulting in an inflammatory response that could accelerate the apoptosis of chondrocytes. ${ }^{56}$ Research ${ }^{56,57}$ in other joints has shown an accelerated progression of joint surface defects in patients with preexisting osteoarthritis. However, these defects can be replaced by fibrocartilage, and many subjects remain asymptomatic. This is why some authors ${ }^{39,58}$ recommend avoiding damaging this joint, since the success of a four- corner fusion procedure is based on the preservation of the radiolunate articular surface. As such, when opting for this technique, it is essential to consider the configuration and entry points of the screws. Today, many surgeons prefer a triangular-shaped screw configuration, ${ }^{59}$ which would decrease the probability of degenerative damage to the radiocarpal joint due to iatrogenic injuries, since the entry point of the screws is at another site. This technique consists of three cannulated screws with entry points from distal to proximal and in a triangular configuration, as described by Ho in $2008 .^{59}$

The mean postoperative flexion-extension ROM in the HCS group was of $68^{\circ}$, which is consistent with that of other 
published series. ${ }^{16,39}$ However, it is worse than the mean value obtained among the plate group: $78^{\circ}$. This last figure is due to a higher extension in this group, and this difference was statistically significant. This finding can have multiple debatable causes, but lunate and DISI reduction are the most relevant, enabling a higher wrist extension; ${ }^{11}$ in fact, a neutral or slightly flexed lunate position is optimal to facilitate wrist extension. ${ }^{41,49}$ There was no dorsal carpal impingement in the plate group, a potential cause of postoperative pain and ROM limitation. Theoretically, one of the advantages of screws compared to plates is avoiding dorsal impingement; however, in our series, not only did this complication not occur, but dorsal extension significantly increased.

The comparison of DASH scores also favored the plate group, who presented a score of 5.3 points against 15.2 points for the screw group, with a statistically significant difference. However, the DASH scores from each group are consistent with those described in the literature (-Table 3).

The dorsal circular plates are the latest materials incorporated as fixation alternatives for four-corner fusion. Their consolidation rates have varied over the years. One of the elements that could play a role in this variation is the difficulty in accurately assessing bone healing, especially with the first spider metal plates (Spider Limited Wrist Fusion Plate, Kineticos Medical Inc., San Diego, CA, US). Kendall et al. ${ }^{41}$ and Vance et al. ${ }^{40}$ reported high non-union rates, of up to $63 \%$. However, in 2008, Merrell et al. ${ }^{43}$ reversed the plate union rates, reporting $100 \%$ of consolidation and few complications; this started a debate about the importance of the technical aspects of the surgery, emphasizing the following points: use of autologous bone graft (distal radius), careful debridement of articular surfaces, adequate debris removal, and placement of at least two screws of adequate size at each corner or bone. When analyzing the reasons for poor outcomes using plates, Weiss ${ }^{44}$ agrees with Merrell et al. $^{43}$ on the importance of the technical aspects of the surgery, and also discusses the origin of the graft and mechanical (not biological) factors, such as the locking construct of the screws to the plate.

In the present study, we used well-known surgical techniques; the Richards et al. ${ }^{16}$ technique for screws, and the Shin ${ }^{11}$ and Rhee et al. $^{45}$ technique and tips for plates. Regarding the surgical approach, note that a posterior interosseous nerve neurectomy was performed in both techniques; although some authors question this procedure due to issues regarding wrist proprioception, we believe that it is an important source of postoperative analgesia and rehabilitation. Furthermore, since partial arthrodesis alters wrist biomechanics, we believe its role in proprioception may be minor.

Regarding bone grafts, we prefer the iliac crest bone graft used in both series due to its advantages and the recommendations made by Shin ${ }^{11}$ and by Rhee et al. ${ }^{45}$ Although there were no theoretical differences regarding the graft donor site (compared to the distal radius), the findings were consistent with those published by Kitzinger et al. in $2012 .^{61}$
In addition, we believe that it is necessary to consider donorsite comorbidity and patient satisfaction.

For the plate group, we used the Xpode dorsal circular plate, a new generation of radiolucent locking implants made of PEEK, a thermoplastic polymer with many benefits in orthopedic applications. $^{62,63}$ The high (100\%) union rate in the present series may also be due to the screw-plate construct. In a biomechanical investigation, Kraisarin et al. ${ }^{52}$ observed that a fixed Xpode plate is the most stable construct compared with the conventional spider dorsal plate or Kirschner wires; in addition, it was the only construct to tolerate a range of simulated forces in motion with no catastrophic failure. Furthermore, its radiolucency enables a more accurate assessment of the consolidation.

Failure of the osteosynthesis material only occurred in two patients treated with screws; both cases were due to osteolysis, and happened after consolidation. In one subject, this complication required a new surgery for removal of the material; in the other case, the patient is waiting for a total wrist arthrodesis, as aforementioned. No failures or need for new surgeries were observed in the plate group. The international literature reports that conventional dorsal circular plates present failure rates from $0 \%$ to $27 \% .{ }^{40-43,53,64}$ The most frequent failures include broken screws due to persistent movement and non-union at the capitate-hamate joint, which highlights the need for at least two screws in each carpal bone (particularly the capitate and lunate bones). Unlike conventional steel plates, there have been few reports of failure of locking plates, suggesting that the PEEK locking dorsal circular plate can provide sufficient fatigue strength in vivo to resist breakage; in addition, the locking mechanism can prevent the screw from breaking at the screw-plate interface. ${ }^{45,65}$ Moreover, the screws of the PEEK locking plate present a variable instead of a fixed angle, which would limit micromovements and facilitate screw fixation loss within the carpal bones.

Although the present work shows relevant data on the different osteosynthesis techniques for four-corner fusion, one of its limitations is the lack of preoperative evaluation, which hinders and assessment of the functional recovery. In addition, it presents the limitations inherent to a nonrandomized study with no blinding.

In conclusion, based on our outcomes and an analysis of the existing literature, we consider both osteosynthesis methods for four-corner fusion reproducible and valid, resulting in adequate consolidation and demystifying the high rates of non-union with dorsal circular plates reported in the literature in the $2000 \mathrm{~s}^{41}$. However, due to the functional outcomes, complications, and secondary surgeries, we believe that the locking dorsal circular plate is the best current alternative for an open four-corner fusion with a dorsal approach, always bearing in mind the details and concerns regarding the surgical technique itself. ${ }^{66}$

Likewise, although cannulated HCSs are an excellent alternative, we currently reserve them for cases in which an arthroscopic surgery is desired, ${ }^{59,67}$ using an arrangement and configuration other than those described by Richards et al. ${ }^{16}$ 


\section{Conflict of interests}

The authors have no conflict of interests to declare.

\section{References}

1 Sawyer GA, Weiss A-PC. Scaphoid Excision and Four-Corner Arthrodesis. Tech Orthop 2009;24(01):58-61

2 Lyons RP, Weiss A-PC. Scaphoid excision and four-corner fusion in the SLAC/SNAC wrist. Oper Tech Orthop 2003;13(01):34-41

3 Tomaino MM, Miller RJ, Cole I, Burton RI. Scapholunate advanced collapse wrist: proximal row carpectomy or limited wrist arthrodesis with scaphoid excision? J Hand Surg Am 1994;19(01): 134-142

4 Campbell AC, Strick MJ. Coalition of the proximal row of the carpus. Ulster Med J 1994;63(01):119-120

5 Delaney TJ, Eswar S. Carpal coalitions. J Hand Surg Am 1992;17 (01):28-31

6 Resnik CS, Grizzard JD, Simmons BP, Yaghmai I. Incomplete carpal coalition. AJR Am J Roentgenol 1986;147(02):301-304

7 Peterson HA, Lipscomb PR. Intercarpal arthrodesis. Arch Surg 1967;95(01):127-134

8 Garcia-Elias M, Lluch A, Ferreres A, Papini-Zorli I, Rahimtoola ZO. Treatment of radiocarpal degenerative osteoarthritis by radioscapholunate arthrodesis and distal scaphoidectomy. J Hand Surg Am 2005;30(01):8-15

9 McAuliffe JA, Dell PC, Jaffe R. Complications of intercarpal arthrodesis. J Hand Surg Am 1993;18(06):1121-1128

10 Sutro CJ. Treatment of nonunion of the carpal navicular bone. Surgery 1946;20:536-540

11 Shin AY. Four-corner arthrodesis. J Am Soc Surg Hand 2001;1(02): 93-111

12 Graner O, Lopes EI, Carvalho BC, Atlas S. Arthrodesis of the carpal bones in the treatment of Kienböck's disease, painful ununited fractures of the navicular and lunate bones with avascular necrosis, and old fracture-dislocations of carpal bones. J Bone Joint Surg Am 1966;48(04):767-774

13 Watson HK. Limited wrist arthrodesis. Clin Orthop Relat Res 1980; (149):126-136

14 Watson HK, Hempton RF. Limited wrist arthrodeses. I. The triscaphoid joint. J Hand Surg Am 1980;5(04):320-327

15 Watson HK, Ballet FL. The SLAC wrist: scapholunate advanced collapse pattern of degenerative arthritis. J Hand Surg Am 1984;9 (03):358-365

16 Richards AA, Afifi AM, Moneim MS. Four-corner fusion and scaphoid excision using headless compression screws for SLAC and SNAC wrist deformities. Tech Hand Up Extrem Surg 2011;15 (02):99-103

17 Pauchard N, Lecoanet-Strugarek C, Segret J, De Gasperi M, Dap F, Dautel G. Dorsal locking plates versus staples in four-corner fusion: a comparative clinical and radiological study. Orthop Traumatol Surg Res 2014;100(06):593-597

18 Mulford JS, Ceulemans LJ, Nam D, Axelrod TS. Proximal row carpectomy vs four corner fusion for scapholunate (Slac) or scaphoid nonunion advanced collapse (Snac) wrists: a systematic review of outcomes. J Hand Surg Eur Vol 2009;34(02):256-263

19 Larsen CF, Jacoby RA, McCabe SJ. Nonunion rates of limited carpal arthrodesis: a meta-analysis of the literature. J Hand Surg Am 1997;22(01):66-73

20 Enna M, Hoepfner P, Weiss AP. Scaphoid excision with four-corner fusion. Hand Clin 2005;21(04):531-538

21 Wyrick JD, Stern PJ, Kiefhaber TR. Motion-preserving procedures in the treatment of scapholunate advanced collapse wrist: proximal row carpectomy versus four-corner arthrodesis. J Hand Surg Am 1995;20(06):965-970

22 Watson HK, Ryu J. Evolution of arthritis of the wrist. Clin Orthop Relat Res 1986;(202):57-67
23 Ashmead D IV, Watson HK, Damon C, Herber S, Paly W. Scapholunate advanced collapse wrist salvage. J Hand Surg Am 1994;19 (05):741-750

24 Allende BT. Osteoarthritis of the wrist secondary to non-union of the scaphoid. Int Orthop 1988;12(03):201-211

25 Harrington RH, Lichtman DM, Brockmole DM. Common pathways of degenerative arthritis of the wrist. Hand Clin 1987;3(04): 507-527

26 Ruby LK, Leslie BM. Wrist arthritis associated with scaphoid nonunion. Hand Clin 1987;3(04):529-539

27 Vender MI, Watson HK, Wiener BD, Black DM. Degenerative change in symptomatic scaphoid nonunion. J Hand Surg Am 1987;12(04):514-519

28 Dacho AK, Baumeister S, Germann G, Sauerbier M. Comparison of proximal row carpectomy and midcarpal arthrodesis for the treatment of scaphoid nonunion advanced collapse (SNAC-wrist) and scapholunate advanced collapse (SLAC-wrist) in stage II. J Plast Reconstr Aesthet Surg 2008;61(10):1210-1218

29 De Smet L, Degreef I, Robijns F, Truyen J, Deprez P. Salvage procedures for degenerative osteoarthritis of the wrist due to advanced carpal collapse. Acta Orthop Belg 2006;72(05):535-540

30 Kiefhaber TR. Management of scapholunate advanced collapse pattern of degenerative arthritis of the wrist. J Hand Surg Am 2009;34(08):1527-1530

31 Goldfarb CA, Stern PJ, Kiefhaber TR. Palmar midcarpal instability: the results of treatment with 4-corner arthrodesis. J Hand Surg Am 2004;29(02):258-263

32 Resnick D, Niwayama G. Carpal instability in rheumatoid arthritis and calcium pyrophosphate deposition disease. Pathogenesis and roentgen appearance. Ann Rheum Dis 1977;36(04):311-318

33 Chen C, Chandnani VP, Kang HS, Resnick D, Sartoris DJ, Haller J. Scapholunate advanced collapse: a common wrist abnormality in calcium pyrophosphate dihydrate crystal deposition disease. Radiology 1990;177(02):459-461

34 Herzberg GCW. Perilunate fracture dislocations. The wrist: diagnosis and operative treatment Vol 1. 1998:651-83

35 Lichtman DM, Bruckner JD, Culp RW, Alexander CE. Palmar midcarpal instability: results of surgical reconstruction. J Hand Surg Am 1993;18(02):307-315

36 Wright TW, Dobyns JH, Linscheid RL, Macksoud W, Siegert J. Carpal instability non-dissociative. J Hand Surg [Br] 1994;19(06): 763-773

37 Watson HK, Goodman ML, Johnson TR. Limited wrist arthrodesis. Part II: Intercarpal and radiocarpal combinations. J Hand Surg Am 1981;6(03):223-233

38 Shapiro JS. Power staple fixation in hand and wrist surgery: new applications of an old fixation device. J Hand Surg Am 1987;12 (02):218-227

39 Ozyurekoglu T, Turker T. Results of a method of 4-corner arthrodesis using headless compression screws. J Hand Surg Am 2012;37 (03):486-492

40 Vance MC, Hernandez JD, Didonna ML, Stern PJ. Complications and outcome of four-corner arthrodesis: circular plate fixation versus traditional techniques. J Hand Surg Am 2005;30(06):1122-1127

41 Kendall CB, Brown TR, Millon SJ, Rudisill LE Jr, Sanders JL, Tanner SL. Results of four-corner arthrodesis using dorsal circular plate fixation. J Hand Surg Am 2005;30(05):903-907

42 Bedford B, Yang SS. High fusion rates with circular plate fixation for four-corner arthrodesis of the wrist. Clin Orthop Relat Res 2010;468(01):163-168

43 Merrell GA, McDermott EM, Weiss AP. Four-corner arthrodesis using a circular plate and distal radius bone grafting: a consecutive case series. J Hand Surg Am 2008;33(05):635-642

44 Weiss A-PC. Results of four-corner arthrodesis using dorsal circular plate fixation. J Hand Surg Am 2006;31(02):327-328, author reply 328 
45 Rhee PC, Kakar S, Shin AY. Four-corner arthrodesis with a locking, dorsal circular polyether-ether-ketone (PEEK-Optima) plate. Tech Hand Up Extrem Surg 2012;16(04):236-241

46 Berger RA, Bishop AT, Bettinger PC. New dorsal capsulotomy for the surgical exposure of the wrist. Ann Plast Surg 1995;35(01): 54-59

47 Tchurukdichian A. A. Scaphoïdectomie et arthrodèse de " 4os " par cupule X-Podeeasy-lock system: technique opératoire, premiers résultats et revue dela littérature. In: Herzberg G, editor. Arthrose péri-scaphoïdienne. Montpellier: Sauramps Médical; 2006:199213

48 Roux JL. Intérêt de l'ostéosynthèse par plaque dans l'arthrodèse des quatre osinternes pour collapsus arthrosique du carpe. . In: Herzberg G, editor. Arthrosepéri-scaphoïdienne. Montpellier: Sauramps Médical; 2006:215-228

49 Cohen MS, Kozin SH. Degenerative arthritis of the wrist: proximal row carpectomy versus scaphoid excision and four-corner arthrodesis. J Hand Surg Am 2001;26(01):94-104

50 Bain GI, Watts AC. The outcome of scaphoid excision and fourcorner arthrodesis for advanced carpal collapse at a minimum of ten years. J Hand Surg Am 2010;35(05):719-725

51 Krakauer JD, Bishop AT, Cooney WP. Surgical treatment of scapholunate advanced collapse. J Hand Surg Am 1994;19(05): 751-759

52 Kraisarin J, Dennison DG, Berglund LJ, An KN, Shin AY. Biomechanical comparison of three fixation techniques used for four-corner arthrodesis. J Hand Surg Eur Vol 2011;36(07):560-567

53 Chung KC, Watt AJ, Kotsis SV. A prospective outcomes study of four-corner wrist arthrodesis using a circular limited wrist fusion plate for stage II scapholunate advanced collapse wrist deformity. Plast Reconstr Surg 2006;118(02):433-442

54 Gohritz A, Gohla T, Stutz N, et al. Special aspects of wrist arthritis management for SLAC and SNAC wrists using midcarpal arthrodesis: results of bilateral operations and conversion to total arthrodesis. Bull Hosp Jt Dis 2005;63(1-2):41-48

55 Skie MC, Gove N, Ciocanel DE, Smith H. Management of nonunited four-corner fusions. Hand (N Y) 2007;2(01):34-38
56 Schulze-Tanzil G. Activation and dedifferentiation of chondrocytes: implications in cartilage injury and repair. Ann Anat 2009; 191(04):325-338

57 Dell'accio F, Vincent TL. Joint surface defects: clinical course and cellular response in spontaneous and experimental lesions. Eur Cell Mater 2010;20:210-217

58 Ball B, Bergman JW. Scaphoid excision and 4-corner fusion using retrograde headless compression screws. Tech Hand Up Extrem Surg 2012;16(04):204-209

59 Ho PC. Arthroscopic partial wrist fusion. Tech Hand Up Extrem Surg 2008;12(04):242-265

60 Lluch A, Salvá G, Esplugas M, Llusá M, Hagert E, Garcia-Elias M. El papel de la propiocepción y el control neuromuscular en las inestabilidades del carpo. Rev Iberoam Cir Mano 2015;43(01): 70-78

61 Kitzinger HB, Karle B, Prommersberger KJ, van Schoonhoven J, Frey M. Four-corner arthrodesis-does the source of graft affect bony union rate? Iliac crest versus distal radius bone graft. J Plast Reconstr Aesthet Surg 2012;65(03):379-383

62 Kurtz SM, Devine JN. PEEK biomaterials in trauma, orthopedic, and spinal implants. Biomaterials 2007;28(32):4845-4869

63 Pokorný D, Fulín P, Slouf M, Jahoda D, Landor I, Sosna A. [Polyetheretherketone (PEEK). Part II: application in clinical practice]. Acta Chir Orthop Traumatol Cech 2010;77(06):470-478

64 Rodgers JA, Holt G, Finnerty EP, Miller B. Scaphoid excision and limited wrist fusion: a comparison of K-wire and circular plate fixation. Hand (N Y) 2008;3(03):276-281

65 Luegmair M, Houvet P. Effectiveness of four-corner arthrodesis with use of a locked dorsal circular plate. Clin Orthop Relat Res 2012;470(10):2764-2770

66 del Piñal F, Klausmeyer M, Thams C, Moraleda E, Galindo C. Early experience with (dry) arthroscopic 4-corner arthrodesis: from a 4-hour operation to a tourniquet time. J Hand Surg Am 2012;37 (11):2389-2399

67 del Piñal F, Tandioy-Delgado F. (Dry) arthroscopic partial wrist arthrodesis: tips and tricks. Handchir Mikrochir Plast Chir 2014; 46(05):300-306 